\title{
MINIMALIST SOLUTION TO WILLIAMSON COUNTY
}

\author{
RAYMOND J. NHAN*
}

\begin{abstract}
Williamson County Regional Planning Commission v. Hamilton Bank of Johnson County relegated Fifth Amendment takings claims to a second-class of federal rights. Before a takings plaintiff can sue in federal court, she must first seek compensation through an "adequate state procedure." Many federal courts have held that requirement to mean a takings litigant must first seek compensation through state courts if that state provides an inverse condemnation proceeding. However, if a takings litigant sues in state court, she will be unable to sue in federal court because of issue preclusion. This effectively shuts the federal courthouse door to many property owners. Only two Supreme Court justices have shown any interest in revisiting Williamson County. Thus, land use attorneys who are concerned about federal court access for takings plaintiffs should craft a case that would attract the Supreme Court's attention. This Article argues that land use lawyers should present the Court with a case in which the property owner has used a non-judicial procedure to seek compensation (such as asking for compensation from a county board). The Court could then rule that such a non-judicial procedure is an "adequate state procedure" that satisfies Williamson County's requirements. This ruling would minimize the negative effects that Williamson County has wrought on takings plaintiffs.
\end{abstract}

\section{INTRODUCTION}

In 1991, Leslie and Ben, a newlywed couple, purchased a quaint three-bedroom home in Pawnee, Indiana-a home in which they

Copyright (C) 2017 Raymond J. Nhan.

${ }^{*}$ Law Clerk United States District Court for the Central District of California. J.D. University of Southern California Gould School of Law 2015; B.A. UC Santa Barbara 2012. The author would like to thank the Duke Environmental Law and Policy Forum editorial staff for all their work in getting this piece ready for publication. The author would also like to thank Wencong Fa, Christopher Kiser, and R.S. Radford for all their helpful comments and suggestions early on in the drafting process. The views expressed in this article are solely those of the author 
hoped to raise a family. ${ }^{1}$ Leslie and Ben came to love Pawnee and the community. When the empty lot across the street went up for sale in 1994, they immediately purchased it as an investment property. They hoped to use the investment proceeds to pay for their children's college education.

Fast-forward 20 years. Leslie and Ben's triplets were high school seniors, and they tried to sell their investment property so that they could use the proceeds to pay for their children's educations. While they were trying to sell their investment property, they learned that Pawnee passed a law, Ordinance 30, five years prior prohibiting all development of their investment property. In other words, Ordinance 30 denied Leslie and Ben all economically beneficial use of their land.

Pawnee's planning commission has an application process in which residents can request compensation for alleged regulatory takings. Leslie and Ben thus went to the planning commission to try to receive compensation for the value of the property they had lost. They submitted documents detailing the value of their property and how they purchased the property as an investment parcel. The planning commission denied their request for compensation.

Soon after, Leslie and Ben sued Pawnee, claiming that Ordinance 30 caused a per se regulatory taking. ${ }^{2}$ Because Leslie and Ben hired a savvy lawyer, they brought their takings claim in Indiana state court. The lawyer was aware of Williamson County Regional Planning Commission v. Hamilton Bank of Johnson City, which requires such takings plaintiffs to ripen their case by seeking compensation through adequate state procedures, ${ }^{3}$ and how some circuit courts interpret "adequate state procedure" to mean seeking just compensation in state court before turning to the federal judiciary. ${ }^{4}$

After Leslie and Ben sued in state court, Pawnee began engaging in gamesmanship. Pawnee removed Leslie and Ben's lawsuit to federal court under 28 U.S.C. $\S 1441$, which allows defendants to remove any claim to federal court if the case could have originally been filed there. ${ }^{5}$

1. Parks and Recreation (NBC Television Broadcast 2009-2015).

2. See Lucas v. S.C. Coastal Council, 505 U.S. 1003, 1019 (1992) (holding property owner suffers a taking when government enacts a regulation that denies all economically beneficial use of property).

3. Williamson Cty. Reg'l Planning Comm'n v. Hamilton Bank of Johnson City, 473 U.S. 172, 194-97 (1985).

4. See, e.g., Murphy v. New Milford Zoning Comm'n, 402 F.3d 342, 354 n. 8 (2d Cir. 2005); Pascoag Reservoir \& Dam, LLC v. Rhode Island, 337 F.3d 87, 92-94 (1st Cir. 2003).

5. This example is based loosely off several actual cases. See, e.g., Sansotta v. Town of Nags Head, 724 F.3d 533, 545 (4th Cir. 2013) (town removing just compensation case from state court 
Because the federal court had subject-matter jurisdiction based on the Fifth Amendment takings claim, ${ }^{6}$ the state court granted Pawnee's motion to remove Leslie and Ben's regulatory takings claim to the Southern District of Indiana.

Two years after Pawnee removed Leslie and Ben's takings claim to federal court, the city moved to dismiss the case as unripe because the couple had not litigated in state court, the adequate state procedure for obtaining compensation. ${ }^{7}$ The Southern District of Indiana agreed with Pawnee and dismissed Leslie and Ben's takings claim as unripe, despite the case having been removed by the city from state court of federal court. ${ }^{8}$

In a final salvo and at great expense, Leslie and Ben filed their claim in state court again. This time, Pawnee litigated the issue through Indiana state court. At the end of the case, the Indiana state court denied Leslie and Ben's just compensation claim. Leslie and Ben then sought to return to federal court to litigate their now-ripe Fifth Amendment just compensation claim. But the Southern District of Indiana invoked San Remo v. County and City of San Francisco, and held that issue preclusion applied to the state court litigation - which Williamson County required they endure. ${ }^{9}$

After years of litigation, Leslie and Ben grew tired. They resigned to the fact that they would never receive just compensation. They gave up.

Leslie and Ben's story is not unusual. ${ }^{10}$ Williamson County has functionally barred property owners from accessing federal court. Indeed, Williamson County makes it very difficult for takings plaintiffs to access any court. ${ }^{11}$ Local governments engage in a procedural game,

to federal court, then arguing case is unripe).

6. 28 U.S.C. $\$ 1331$ (2012).

7. Sansotta, 724 F.3d at 545.

8. In fact, courts have used Williamson County's requirement to send cases to state court, even after the government removes a case, and agrees that jurisdiction is proper in federal court. See, e.g., Save More Food Mkts, Inc. v. Wis. Dep't of Transp., No. 16-cv-447-jdp, 2016 WL 4131866 (W.D. Wisc. Aug 3, 2016).

9. San Remo Hotel, L.P. v. City \& Cty. of San Francisco, 545 U.S. 323, 335 (2005).

10. See, e.g., Sansotta, 724 F.3d 533; Winer v. Clay Township, No. 3:15-cv-276, 2016 WL 3676717 (S.D. Ohio July 6, 2016); Gelentt v. Township of Chapman, No. 4:15-cv-1910, 2015 WL 7454757 (M.D. Pa. Nov. 24, 2015).

11. See Michael Berger, Supreme Bait \& Switch: The Ripeness Ruse in Regulatory Takings, 3 WASH. U. J.L. \& POL'Y 99, 106-09 (2000) (hereinafter Bait \& Switch) (explaining the Dodd 
like the kind that Pawnee used with Leslie and Ben, to prevent takings litigants from having their day before a judge.

But in April 2016, takings plaintiffs received a welcoming sign. Though the Supreme Court denied certiorari in Arrigoni Enterprises $v$. Town of Durham, a case asking the Court to revisit Williams County, Justice Thomas dissented from denial of certiorari. ${ }^{12}$ In his dissent from denial, which Justice Kennedy joined, Justice Thomas noted that "the justification for Williamson County's state-litigation requirement are suspect, while its impact on takings plaintiffs is dramatic."13 $\mathrm{He}$ noted that Williamson County has inspired "gamesmanship" from lower courts ${ }^{14}$-like that which Pawnee used. Though the Supreme Court did not accept Arrigoni, some Justices are apparently aware of Williamson County's shell game ${ }^{15}$ and are looking to overrule it. Coupled with Chief Justice Rehnquist's concurrence in San Remo, which questioned Williamson County's logic, ${ }^{16}$ property rights advocates may have cautious optimism that the Court will soon eliminate the state litigation rule.

Now that some Justices have signaled their interest in revisiting Williamson County, property rights experts and jurisdictional mavens must present a "cert-worthy" case to the Court. ${ }^{17}$ Many considerations go into deciding whether a case is "cert-worthy," such as identifying a circuit split, ${ }^{18}$ but many commentators have written about Williamson County's incoherence and why the court should overrule it. ${ }^{19}$ Instead of asking the Court to overrule Williamson County, plaintiffs should provide the Justices an opportunity to make incremental changes.

family's and the Rainey brother's struggle to get a court to hear their takings case).

12. Arrigoni Enters., LLC v. Town of Durham, 136 S. Ct. 1409 (2016) (Thomas, J., dissenting from denial).

13. Id. at 1409 (internal quotation marks and brackets omitted).

14. Id.

15. See generally Michael Berger \& Gideon Kanner, Shell Game! You Can't Get There from Here: Supreme Court Ripeness Jurisprudence in Takings Cases at Long Last Reaches the Selfparody Stage, 36 URB. L 671 (2004).

16. San Remo, 545 U.S. at 352 (Rehnquist, C.J., concurring).

17. Certainly, lower courts may take the same steps I propose the Supreme Court take to undo the damage that Williamson County has caused.

18. Evan Bernick, The Circuit Splits are Out There-And the Court Should Resolve Them, 16 ENGAGE 36, 36 (2015) ("[Chief Justice John Roberts] emphasized that circuit splits are far and away the most important consideration in deciding whether to grant cert petitions.").

19. See, e.g., Bait \& Switch, supra note 11; Joshua D. Hawley, The Beginning of the End? Horne v. Dep't of Agriculture and the Future of Williamson County, 2013 CATO SUP. CT. REV. 245, 245 (2015); R.S. Radford \& Jennifer Fry Thompson, The Accidental Abstention Doctrine: After Thirty Years, the Case for Diverting Federal Takings Claim to State Court Under Williamson County Has Yet to Be Made, 67 BAYLOR L. REV. 567, 612-13 (2015). 
Justices prefer incremental changes to overruling cases. ${ }^{20}$ Therefore, the opportunity to make a narrow ruling would be more attractive to the Court.

Thus, property owners should provide the Court with an opportunity to narrow Williamson County without overruling it. ${ }^{21}$ Plaintiffs should present the Court with an opportunity to make a minimalist ruling that would modify Williamson County's drastic consequences, and this Article explains how it can be done. An ideal minimalist case would eliminate the ripeness-removal and Williamson County-San Remo traps that plagued Leslie and Ben. By eliminating these two traps, the Court can ensure that takings litigants can have their cases heard in federal court.

To accomplish this solution, this article proceeds in three parts. Part I lays out the history of Williamson County, San Remo, and how the ripeness-removal and Williamson County-San Remo traps came to be. Part II addresses why the Court should fix Williamson County's defects. Finally, Part III provides a minimalist solution to the ripenessremoval and Williamson County-San Remo traps: interpret "adequate state procedure" to mean any non-judicial state procedure that can provide compensation.

\section{JUST COMPENSATION AND RIPENESS}

\section{A. Williamson County and the Origins of a Ripe Mess}

In 1973, Temple Hill County Estates began developing its property after the Williamson County Planning Commission approved its development plans. ${ }^{22}$ In 1977, the Planning Commission changed the county's zoning requirements. ${ }^{23}$ Though the Planning Commission previously approved Temple Hill's plat submissions, it rejected them in 1980. ${ }^{24}$ Because of the decision, Temple Hill's land became undevelopable. ${ }^{25}$ Hamilton Bank then foreclosed on the property and

20. See Diane S. Sykes, Minimalism \& Its Limits, 2015 CATO Sup. CT. REV. 17, 17-18 (2015) (discussing minimalism during the Roberts Court).

21. Cf. id. at 19 ("On a more philosophical level, modern minimalism promotes itself as a hedge against judicial supremacy. It calls on judges to go slowly and in small steps.”).

22. Hamilton Bank of Johnson City v. Williamson Cty. Reg'l Planning Comm'n, 729 F.2d 402, 403 (6th Cir. 1984).

23. $I d$.

24. Id.

25. See id. 
sued the Planning Commission for an unconstitutional regulatory taking. ${ }^{26}$

The District Court granted a judgment notwithstanding the jury verdict for the commission on the takings claim. ${ }^{27}$ That court held that there was no taking, reasoning that Tennessee law estopped the Planning Commission from applying the regulation that allegedly caused the taking. ${ }^{28}$ The Sixth Circuit reversed, holding that evidence supported the jury verdict and finding that there was a taking because the Commission denied the bank all economic use of its land for some time. $^{29}$ The Supreme Court granted certiorari to decide whether "Federal, State, and Local government must pay money damages to a landowner whose property allegedly had been 'taken' temporarily by application of government regulation." 30

Instead of answering this question, the Court created a novel jurisdictional rule for Fifth Amendment claims. First, the Court reasoned that Hamilton Bank's claim was unripe. ${ }^{31}$ It said that the bank had not received a final decision regarding its zoning ordinance because it did not seek variances that would have allowed it to develop its land. ${ }^{32}$ Second, the Court held that a Fifth Amendment claim is unripe until the state actor denies just compensation. If a state provides "adequate procedure" to obtain just compensation, property owners cannot claim a Fifth Amendment violation until they seek and are denied compensation through a state procedure. ${ }^{33}$ The Court wrote that the government violates the Fifth Amendment only when it takes property and fails to pay compensation. ${ }^{34}$ This means takings plaintiffs must first seek compensation from the state or local government before suing in federal court. ${ }^{35}$

Williamson County's ripeness rule can be distilled into two prongs: a plaintiff's taking claim is unripe until (1) the government makes a final decision and (2) the claimant seeks just compensation through an adequate state procedure for obtaining compensation and is denied. ${ }^{36}$

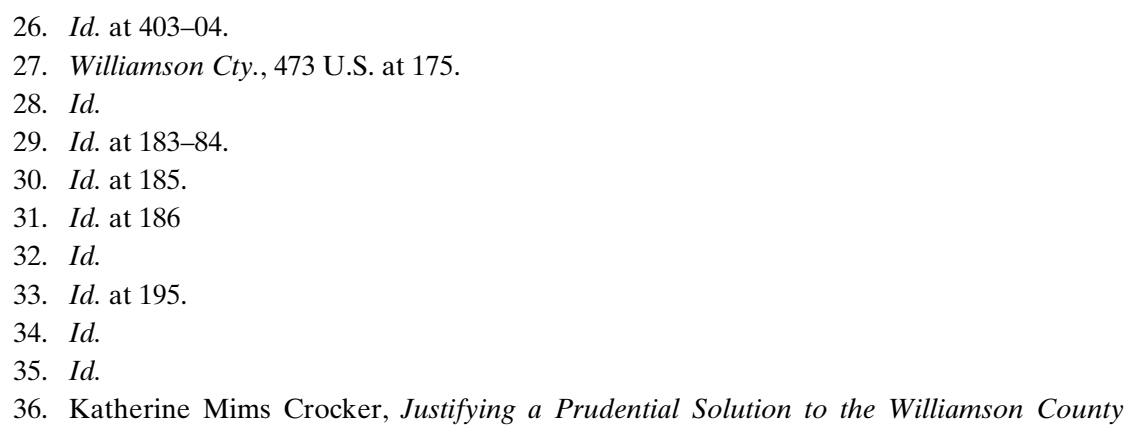




\section{B. San Remo Hotel v. City and County of San Francisco}

Property owners immediately felt Williamson County's effects. If a takings plaintiff complied with Williamson County by seeking compensation through state court, then a federal court could not hear his case because of claim or issue preclusion. In other words, a valid state court decision prevents a federal court from hearing a case based on the same factual scenario. Most circuits declined to create an exception to the preclusion rule, even if the plaintiff was forced to go through state court to satisfy Williamson County. ${ }^{37}$ Only the Second Circuit constructed an exemption to the preclusion rule when a litigant was forced to go through state court litigation. ${ }^{38}$

The Supreme Court addressed this circuit split in San Remo. That case presented a straightforward question: "Is a Fifth Amendment Takings claim barred by issue preclusion based on a judgment denying compensation solely under state law which was rendered in a state court proceeding that was required to ripen the Federal Takings claim?" 39 Writing for the Court, Justice Stevens framed the issue differently. He asked whether "federal courts may craft an exception to the full faith and credit statute . . . for claims brought under the Takings Clause." ${ }^{40}$

In San Remo, the San Francisco Board of Supervisors forbade the San Remo Hotel from converting rooms for tourists use without reapplying and paying a fee. ${ }^{41}$ In response, the hotel sued the Board for causing a taking. After San Remo sued in state court, the parties stayed the case while the hotel litigated in federal court. ${ }^{42}$ The Ninth Circuit applied Pullman abstention ${ }^{43}$ to the case, reasoning that the

Ripeness Puzzle, 49 GA. L. REV. 163, 166-68 (2014).

37. See, e.g., Wilkinson v. Pitkin Cty. Bd. of Cty. Comm'rs, 142 F.3d 1319, 1324 (10th Cir. 1998) ("We conclude the Williamson ripeness requirement is insufficient to preclude application of res judicata and collateral estoppel principles in this case."); Palomar Mobilehome Park Ass'n v. City of San Marcos, 989 F.2d 362, 364-65 (9th Cir. 1993) (holding that res judicata bars federal takings claim); Peduto v. City of N. Wildwood, 878 F.2d 725, 729 (3d Cir. 1989) (same); but see Fields v. Sarasota Manatee Airport Auth., 953 F.2d 1299, 1305-06 (11th Cir. 1992) (recognizing a limited exception to the applicability of res judicata and collateral estoppel to federal takings claims). 2003).

38. Santini v. Connecticut Hazardous Waste Mgmt. Serv., 342 F.3d 118, 127-28 (2d Cir.

39. Brief for Petitioner at i, San Remo, 545 U.S. 323, 2005 WL 176427.

40. San Remo, 545 U.S. at 326.

41. Id. at 329 .

42. Id. at 330 .

43. Pullman abstention allows a federal court to decline to hear a lawsuit if a ruling on state law could resolve the federal constitutional claim; federal courts should avoid deciding the claim 
state court's decision might moot the federal question. ${ }^{44}$ The Ninth Circuit also held that one of the San Remo's takings claim might be unripe because it did not seek compensation in state court through an inverse condemnation proceeding. ${ }^{45}$

Before returning to state court, San Remo reserved its right to reenter federal court through England reservation. ${ }^{46}$ That reservation was created in England v. Louisiana Board of Medical Examiners, where the Court held that a party litigating in state court because of abstention may reserve the right to bring his federal claim in federal court after state litigation concludes. ${ }^{47}$ The Eastern District of Louisiana abstained from hearing England because it found that a state court may have resolved the case on state law grounds. ${ }^{48}$ But after receiving an adverse decision in Louisiana state court, the plaintiffs sought to return to federal court. ${ }^{49}$

The England Court stressed that plaintiffs have a right to sue in federal court. ${ }^{50}$ Justice Brennan wrote, "[T]here are fundamental objections to any conclusion that a litigant who has properly invoked the jurisdiction of a Federal District Court to consider federal constitutional claims can be compelled, without his consent and through no fault of his own, to accept instead a state court's determination of those claims." ${ }^{11} \mathrm{He}$ concluded, "[T]he right of a party plaintiff to choose a Federal court where there is a choice cannot be properly denied." 52

San Remo, after losing its state takings claim in the California Supreme Court, ${ }^{53}$ sought to use the England reservation and return to litigate its federal takings claim in federal court. But the district court held that issue preclusion prevented San Remo from raising its federal claim if it could have been resolved in state court. ${ }^{54}$ The Ninth Circuit upheld the district court's decision, holding that neither Williamson

until the state court has an opportunity to address the state law issue. Railroad Comm'n of Tex. v. Pullman Co., 312 U.S. 496 (1941).

44. San Remo, 545 U.S. at 330.

45. Id. at 331 .

46. Id.

47. England v. La. State Bd. of Med. Exam'rs, 375 U.S. 411, 421-22 (1964).

48. Id. at 413 .

49. Id. at $413-14$.

50. Id. at 415 .

51. Id.

52. Id. (internal quotations and citations omitted).

53. San Remo Hotel, L.P. v. City \& Cty. of San Francisco, 41 P.3d 87, 87 (Cal. 2002).

54. San Remo, 41 P.3d at 91. 
County, England, nor Pullman affected the court's full faith and credit inquiry. ${ }^{55}$

Despite Justice Brennan's explanation in England that a litigant may return to federal court by "making on the state record the reservation to the disposition of the entire case by the state courts," the Court upheld the lower court's determination. Justice Stevens explained:

Typical England cases generally involve federal constitutional challenges to a state statute that can be avoided if a state court construes the statute in a particular manner. In such cases, the purpose of abstention is not to afford state courts an opportunity to adjudicate an issue that is functionally identical to the federal question. To the contrary, the purpose of Pullman abstention in such cases is to avoid resolving the federal question by encouraging a state-law determination that may moot the federal controversy. ${ }^{57}$

San Remo's majority also rejected the argument that issue preclusion should not apply when plaintiffs are forced into state court. ${ }^{58}$ The Court expressly rejected the Second Circuit decision, Santini v. Connecticut Hazardous Waste Management Service. The Second Circuit had held that a plaintiff could reserve his claim for federal court review if he is forced to sue in state court because of Williamson County. ${ }^{59}$ The court sought a "middle ground" because, "It would be both ironic and unfair if the very procedure that the Supreme Court required plaintiffs to follow before bringing a Fifth Amendment takings claim-a state-court inverse condemnation action-also precluded [plaintiffs] from ever bringing a Fifth amendment takings claim." The court interpreted that, in Williamson County, the Supreme Court did not intend "to deprive all property owners in states whose takings jurisprudence generally follows federal law (i.e., those to whom collateral estoppel would apply) of the opportunity to bring the Fifth Amendment takings claim in federal court." ${ }^{60}$

55. San Remo Hotel, L.P. v. City \& Cty. of San Francisco, 364 F.3d 1088, 1096-98 (9th Cir. 2004).

56. England, 375 U.S. at 339-40 (internal citations and quotations omitted).

57. San Remo, 545 U.S. at 339-40 (internal citations and quotations omitted).

58. Id. at $341-42$.

59. Santini, 342 F.3d at 118.

60. Id. at 130 . 
But Justice Stevens dismissed the Second Circuit's argument, reasoning that there is no right to have a federal claim vindicated in a federal forum. ${ }^{61}$

Recognizing the dilemma that the Second Circuit identified, Chief Justice Rehnquist wrote a concurrence, joined by three other justices, which questioned the logic of Williamson County. The Chief Justice agreed that the full faith and credit statute precluded federal court review in San Remo. ${ }^{62}$ But the Chief Justice was unsure why a claimant must seek compensation in state court before going to federal court. ${ }^{63}$ He questioned the underlying idea that state courts were better than federal courts at resolving land use cases. ${ }^{64}$ In addition, he observed that plaintiffs may bring their land use claims directly to federal court if they involve other constitutional rights, like the First Amendment or the Equal Protection Clause. ${ }^{65}$ The Chief Justice insisted that Williamson County led to an absurd result and put the Fifth Amendment in an inferior constitutional position. Though he did not explicitly call for Williamson County to be overruled, Chief Justice Rehnquist suggested that he thought its reasoning was suspect and that the Court should reconsider the case. ${ }^{66}$

\section{The Emergence of the Ripeness-Removal and Williamson} County-San Remo Traps and the Efforts to Untangle Them.

After San Remo, the ripeness-removal and Williamson CountySan Remo traps fully formed, making it nearly impossible for takings litigants to sue in federal court. The ripeness-removal trap arises when a property owner files a takings claim in state court, following Williamson County's requirements, but the government then removes the Fifth Amendment claim to federal court based on subject matter jurisdiction. ${ }^{67}$ Once the case is in federal court, the government argues

61. San Remo, 545 U.S. at 342 (citing Migra v. Warren City School Dist. Bd. of Educ., 465 U.S. 75, 84 (1984); Allen v. McCurry, 449 U.S. 90, 103-04 (1980)).

62. Id. at 348 (Rehnquist, C.J., concurring).

63. Id. at 349 .

64. Id. at 350

65. Id. at 350-51 (citing Renton v. Playtime Theatres, Inc., 475 U.S. 411 (1986); Cleburne v. Cleburne Living Ctr., Inc., 473 U.S. 432 (1985); Young v. American Mini Theatres, Inc., 427 U.S. 50 (1976); Vill. of Bele Terre v. Boraas, 416 U.S. 1 (1974)).

66. See id (explaining that state courts are competent to adjudicate federal takings doesn't explain why federal courts should be restrained from hearing just compensation cases).

67. Indeed, local government lawyers have not hesitated to use the ripeness-removal trap against property owners. See, e.g., Sansotta, 724 F.3d at 547-48; Mecouch v. Pension Bd. of the Employee's Retirement Systems of the Cty. of Milwaukee, 184 F.Supp.3d 684, 689 (E.D. Wisc. 2016); Gelnett v. Twp. of Chapman, 2015 WL 7454757 at*1 (M.D. Penn. Nov. 24, 2015). 
that the landowner's case must be dismissed because the litigant has not used an adequate procedure for obtaining compensation. Often, courts hold that these cases are unripe because the litigant did not go through state court to seek just compensation. ${ }^{68}$ This is so even though the property is only in federal court because the government removed their case. ${ }^{69}$

The Williamson County-San Remo trap occurs when a takings litigant unsuccessfully seeks compensation in state court. ${ }^{70}$ Because he has sought compensation in state court, issue preclusion applies to the takings claim and he will be unable to sue in federal court. ${ }^{71}$ In other words, the procedure that ripens a case for federal review also prevents federal courts from hearing the issue..$^{72}$

Fortunately, for takings litigants, the Supreme Court and circuit courts have lessened the impact of these traps. The Court has repeatedly held that Williamson County's ripeness rule is a prudential doctrine, not a jurisdictional requirement. ${ }^{73}$ Jurisdictional requirements are constitutionally mandated and must be satisfied before a court may hear a case. ${ }^{74}$ On the other hand, prudential requirements are court-developed policies that allow the judiciary to decline to hear some cases even where jurisdiction exists. ${ }^{75}$ Because Williamson County is only prudential, a federal court may hear a just compensation case even if Williamson County's requirements are not

68. See, e.g., Gelnett, 2015 WL 7454757 at *4 (bypassing state court "streamlines litigation by dispensing with needless discovery and fact-finding").

69. Id.

70. Scott A. Keller, Note, Judicial Jurisdiction Stripping Masquerading as Ripeness: Eliminating the Williamson County State Litigation Requirement for Regulatory Takings Claims, 85 TEX. L. REV. 199, 200 (2006) ("When combined with preclusion doctrines, the Williamson County State Litigation prong prevents a substantial majority of takings plaintiffs from litigating their claims in federal court.").

71. Issue preclusion is an estoppel doctrine that prevents a person from re-litigating an issue that another court has decided. Eli J. Richardson, Taking Issue with Preclusion: Reinventing Collateral Estoppel, 65 Miss L.J. 41, 41, 45-47 (1995). Essentially, when the same issue was before another court, issue preclusion will apply. This principle is constitutionally mandated per the Full Faith and Credit Clause of the United States Constitution. U.S. CONST. art. IV, $§ 1$.

72. See San Remo, 545 U.S. at 351 (Rehnquist, J., concurring) (discussing how the RookerFeldman Doctrine could cause a preclusion issue).

73. See, e.g., Stop the Beach Renourishment v. Florida Dep't of Envtl. Protection, 560 U.S. 702, 742 (2010); Suitum v. Tahoe Reg'l Planning Agency, 520 U.S. 725, 733-34 (1997).

74. See Lujan v. Def. of Wildlife, 504 U.S. 555, 560 (1992) ("[T]he core component of standing is an essential and unchanging part of the case-or-controversy requirement of Article III").

75. See generally Bradford C. Mank, Is Prudential Standing Jurisdictional, 64 CASE W. RES. L. REV. 413, 419-26 (2013) (discussing the differences between prudential and jurisdictional standing). 
satisfied. ${ }^{76}$ Thus, Williamson County's prudential nature may help property owners access federal court without worrying about issue preclusion. $^{77}$

Because Williamson County is not a constitutional mandate, some courts have held that its requirements may be waived. ${ }^{78}$ The Fourth and Sixth Circuits have functionally eliminated the ripeness-removal trap, partially by recognizing this rule. In Sansotta, a town removed a takings case properly filed in state court to federal court. ${ }^{79}$ A year after removing the case, the town argued that Sansotta's claim was unripe because he did not seek compensation in state court. ${ }^{80}$ The Fourth Circuit rejected the Town's argument, explaining that it would not tolerate gamesmanship. ${ }^{81}$ The court held that the government waives Williamson County's prudential requirement if it removes a case to federal court. ${ }^{82}$ According to the Fourth Circuit, a defendant cannot accede to federal jurisdiction by removing a takings case and then argue that the federal court does not have jurisdiction. ${ }^{83}$ Moreover, heavily relying on Sansotta, the Sixth Circuit made a similar holding in Lily Investments. ${ }^{84}$

By recognizing the waiver rule, the Fourth and Sixth Circuits ensure that takings plaintiffs will at least be able to present their claims

76. See Lujan, 504 U.S. at 560 (discussing the difference between prudential and jurisdictional standing requirements).

77. The futility exception has also weakened Williamson County. That rule allows for immediate access to federal court if "recourse to state courts would be futile" because state law already resolved an issue. Hacienda Valley Mobile Estates v. City of Morgan Hill, 353 F.3d 651, 655 (9th Cir. 2003). For instance, in Cedar Point Nursey v. Gould, the court held that the Fifth Amendment litigant did not have to comply with Williamson County because California state case law already resolved the issue in a disfavorable way. 1:16-cv-00185-LJO-BAM, 2016 WL 1559271, at *4 (E.D. Cal. Apr. 18, 2016). Because suing in California court would be futile, the court held that Williamson County did not apply. Id. (citing Agric. Labor Relations Bd. v. Superior Court, 16 Cal.3d 392, 411 (1976) for the proposition that an access regulation does not cause a taking under the California or United States Constitutions, thus foreclosing recovery in California state court).

78. See, e.g., Lily Investments v. City of Rochester, No. 15-2289, 2017 WL 56753 (6th Cir. Jan. 5, 2017); Sherman v. Town of Chester, 752 F.3d 554, 554 (2d. Cir. 2014); Sansotta, 724 F.3d at 533.

79. Sansotta, 724 F.3d at 533 .

80. Id. at 536 .

81. Id. at 545 .

82. Id; see also Guggenheim v. City of Goleta, 638 F.3d 1111, 1117 (9th Cir. 2010) (en banc) (recognizing that cities may waive Williamson County ripening requirements).

83. Sansotta, 724 F.3d at 545.

84. See id. at 546-47 ("[P]ermitting a state or its political subdivision to assert this requirement after the state or its political subdivision has removed the case to federal court would allow the state... to invoke federal jurisdiction and then object to federal jurisdiction"); Lily Investments, 2017 WL 56753 at *7. 
to some court. If a takings litigant tries to comply with Williamson County by litigating in state court, the court will have jurisdiction to hear his takings claim because state courts can have jurisdiction over such issues in limited circumstances. ${ }^{85}$ Alternatively, if the government removes a takings claim to federal court, then the government acceded to federal review, and that court has jurisdiction.

However, it is not enough that Williamson County is a prudential doctrine or waivable. Too many courts stringently apply Williamson County, making it impossible to escape the ripeness-removal and Williamson County-San Remo traps. ${ }^{86}$ Constitutional protections should not depend on whether one lives in North Carolina or Indiana. ${ }^{87}$ If Leslie and Ben lived in Charlotte, a city located in the Fourth Circuit, they could have remained in federal court after Pawnee removed their case from state court. Unfortunately, for Leslie and Ben, Indiana is in the Seventh Circuit, which stringently applies Williamson County.

Accordingly, as things stand, the right to seek just compensation depends on what part of the country one lives in.

\section{THE CONSTITUTIONAL PROMISE - WHY WILLIAMSON COUNTY UNDERMINES OUR CONSTITUTIONAL STRUCTURE AND MUST BE ADDRESSED}

In this section, I highlight why the Court should address Williamson County. First, I discuss the federal court's' responsibility to hear just compensation cases and how Williamson County undermines this duty. Second, I highlight how Williamson County has created a two-track justice system for different constitutional rights. Third, I explain how Williamson County discriminates against the neediest members of society.

85. Jason Mazzone, When the Supreme Court is Not Supreme, 104 Nw. U. L. REV. 979, 99495 (2010) (discussing situations in which state courts keep jurisdiction, such as with independent state law questions).

86. See, e.g., Sunrise Detox V, LLC v. City of White Plains, 769 F.3d 118, 124 (2d Cir. 2014) (applying Williamson County to an Americans with Disabilities Act case involving a land use issue).

87. Compare Sansotta, 724 F.3d at 544-50 (explaining why the Fourth Circuit permits waiver of Williamson County), with Peters v. Vill. of Clifton, 498 F.3d 727, 734 (7th Cir. 2007) (rejecting argument that Williamson County should not apply because it is prudential, explaining " $\mathrm{t}] \mathrm{he}$ prudential character of the Williamson County requirements do not, however, give the lower federal courts license to disregard them"). 


\section{A. Williamson County Undermines the Just Compensation Clause's Guarantees and the Federal Judiciary's Responsibility to Hear Just Compensation Cases}

The Fifth Amendment is a self-executing constitutional provision that guarantees just compensation whenever the government takes someone's property. ${ }^{88}$ Government must pay for both physical and regulatory takings. ${ }^{89}$ As with other federal constitutional provisions, federal courts seemingly have a responsibility to hear federal questions.

Proponents of Williamson County's ripeness rule might ask why are federal courts responsible for providing a constitutional remedy? Certainly, state courts have concurrent responsibility to hear federal constitutional claims..$^{90}$ In San Remo, Justice Stevens noted that issue preclusion applies "even when the plaintiff would have preferred not to litigate in state court, but was required to do so because of prudential rules." J1 Justice Stevens argued that there is no right to litigate in federal court, citing Migra v. Warren City School District Board of Education and Allen v. McCurry. ${ }^{92}$

88. United States v. Clarke, 445 U.S. 253, 257 (1980) ("the self-executing character of the constitutional provision with respect to compensation ..." (citing 6 P. Nichols, Eminent Domain $\$ 25.41$ (3d rev.ed.1972)); Thomas Merrill, Anticipatory Remedies for Takings, 128 HARV. L. REV. 1630, 1637 (2015) ([T]he Takings Clause includes an anticircumvention principle to the effect that the government cannot avoid its obligation to pay compensation by declining to exercise the power of eminent domain when in all fairness and justice it should do so." (citations and quotation omitted)).

89. A physical taking occurs when the government occupies one's land. Loretto v. Teleprompter Manhattan CATV Corp., 458 U.S. 419, 426 (1982) ("[A] permanent physical occupation authorized by government is a taking without regard to the public interests that it may serve."). On the other hand, a regulatory taking involves the government imposing a regulation that "goes too far" and destroys the value of one's property. Penn. Coal Co. v. Mahon, 260 U.S. 323, 415 (1922) ("The general rule at least is that while property may be regulated to a certain extent, if regulation goes too far it will be recognized as a taking.").

90. Robb v. Connolly, 111 U.S. 624, 624 (1884); Martin v. Hunter's Lessee, 14 U.S. 304, 339 (1816); Samuel P. Jordan, Reverse Abstention, 92 B.U. L. Rev. 1771, 1789 (2012).

91. San Remo, 545 U.S. at 342.

92. Id. These cases are easily distinguishable though. In Migra, the Court held that a teacher who successfully sued the school district she worked for and its administration in state court could not bring a Section 1983 suit in federal court based on the same facts later on. Because she has already litigated the core facts in state court, she could not now litigate the same issues in federal court. Unlike in Migra, San Remo Hotel had the rug pulled under its feet. San Remo, 545 U.S. at 328 (denying opportunity to reserve claim under England). In Allen, a heroin dealer brought a $\S$ 1983 suit in federal court against the St. Louis Police Department after a police officer violated his Fourth Amendment rights. 449 U.S. at 92-93. However, the Supreme Court held that res judicata applied to the dealer's claim because the search and seizure issue had been litigated during his state court trial. Thus, the federal judiciary would not provide the dealer a second chance to re-litigate his claims because he should have brought his $\S 1983$ claim with his 
However, even if preclusion properly applied in Migra and Allen, federal courts still have a responsibility to resolve federal issues and play a necessary role in protecting constitutional rights. ${ }^{93}$ In its earliest days, the Court explained that federal courts bring finality and unity to points of contention. ${ }^{94}$ Article III of the Constitution requires that federal courts be able to provide the last word for federal questions. ${ }^{95}$ Although state courts play an important role in enforcing constitutional rights, federal courts ultimately must define them. ${ }^{96}$ When federal courts, namely the Supreme Court, provide the final say for constitutional provisions, they ensure that rights are protected equally across the country.

If states are mainly responsible for determining the Fifth Amendment's constitutional minima, some states could provide the ability to receive just compensation while others may not. ${ }^{97}$ Indeed, a state judiciary hostile to property rights may provide protections well below what the Supreme Court or any other federal court would provide. ${ }^{98}$ Although the Supreme Court could ultimately resolve any major conflicts between state courts, the chances of Supreme Court review are low. ${ }^{99}$ Even if the Supreme Court corrects erroneous decisions, it may be difficult, if not impossible, for those who have had their constitutional rights violated ever to get just compensation.

suppression motion.

93. See San Remo, 545 U.S. at 348 (Rehnquist, J., concurring) (citing Migra and Allen for the proposition that preclusion properly applied in San Remo).

94. Id. at 348; Michael J. Gerhardt, What's Old is New Again, 86 B.U. L. Rev. 1267, 1283 (2006) ("While it is true that claimants redirected into state courts by the proposed federal measures would still have access to a judicial forum, they would be denied at least two essential features of the federal court system - finality and uniformity.").

95. Akhil Reed Amar, Of Sovereignty \& Federalism, 96 Yale L.J. 1425, 1511 (1987).

96. Id.

97. Compare Norwood v. Horney, 110 Ohio St.3d 353, 356 (2006) (rejecting economic development as a public use), with Kaufmann's Carousel v. City of Syracuse Indus. Dev. Agency, 301 A.D.2d 292, 294 (N.Y. App. Div. 4th Dep't 2002) (accepting a broad definition of public use, including economic development).

98. To be sure, it may be the case that "adequate procedures" are inadequate. State courts may use Williamson County's requirement to avoid hearing land use cases. See Gregory Overstreet, 10 J. LAND USE \& ENVTL. L. 91, 123-24 (1994) ("The tragic irony of the ripeness doctrine a cue from their federal counterparts, claims unripe based on a borrowed.").

99. See Aaron Tang, The Ethics of Opposing Certiorari Before the Supreme Court, 35 HARV. J.L. \& PUB POL'Y 933, 934-35 (2012). 


\section{B. Williamson County Creates a Two-Tracked Justice System for Constitutional Claims}

Williamson County's ripeness rule creates barriers for takings cases that are not present for other constitutional claims. ${ }^{100}$ Even when courts analyze a law's constitutionality by looking at local practices, there is no blanket ban prohibiting certain constitutional claims from being heard in federal court. Take the Miller test: courts use this test to determine whether a work is obscene and not protected by the First Amendment. ${ }^{101}$ In conducting the Miller test, courts look to local standards to define "prurient interest" and to state law to determine whether a work is patently offensive. ${ }^{102}$ But they consult national standards to determine whether the work of art has any artistic value. ${ }^{103}$ Claimants who allege that a city official violated their First Amendment right by censoring their works do not have to ripen their case in state court. ${ }^{104}$ This is the case, even though it may be that state judges would be in a better position to decide what a prurient interest in their communities is. ${ }^{105}$ If the Supreme Court imposed a statelitigation rule for Miller claims, there would be shock and criticism. ${ }^{106}$

100. Cf. Kelo v. City of New London, 545 U.S. 469, 518 (Thomas, J., dissent, 2005) ("The Court has elsewhere recognized 'the overriding respect for the sanctity of the home that has been embedded in our traditions since the origins of the Republic, when the issue is only whether the government may search a home. Yet today the Court tells us that we are not to 'second-guess the City's considered judgments,' when the issue is, instead, whether the government may take the infinitely more intrusive step of tearing down petitioners' homes.").

101. To be sure, the Miller test is often-criticized. Jessica Fisher, Brown v. Entertainment Merchants Ass'n: "Modern Warfare” On First Amendment Protection of Violent Video Games, 8 J. BUS. \& TECH. L. 525, 546 (2013). Even so, the Miller test is still good law and used to determine whether artistic work is obscene and falls outside First Amendment protections. Miller v. California, 413 U.S. (1973). There are three prongs to this test. First, a court must determine whether the work appeals to the prurient interest. Id. at 24. Courts look at local standards to determine what the "prurient interest" is. $I d$. Second, a court must determine whether the work depicts in a patently offensive way, sexual conduct or excretory functions. Id. at 24-25 Courts look to state law to determine this prong. Id. Third, the court must determine whether the work, taken as a whole, lacks any serious literary, scientific, artistic, or political value. $I d$. at 24 . Courts use national standards to analyze this prong. $I d$.

102. Id. at 24 .

103. Id. at 30 .

104. See generally Eclipse Enter., Inc. v. Gulotta, 134 F.3d 63 (2d. Cir. 1997) (no issue when the First Amendment claim was first brought in federal district court).

105. See id.

106. Cf. Michael Kent Curtis, The Fraying Fabric of Freedom: Crisis \& Criminal Law in Struggles for Democracy \& Freedom of Expression, 44 TEX. TECH L. REV. 89, 94 (2011) (discussing English commentary describing free speech as sacred). 
Commentators would condemn the Court and stress that free speech is a fundamental right. ${ }^{107}$

Equal protection claims are also not subject to an "adequate state procedure" requirement. The Court could hold that Texas or California cannot violate the Equal Protection Clause until one seeks all potential state court remedies and those states deny recourse. ${ }^{108}$ For instance, if California has a state constitutional provision that prohibits discrimination based on race, the Supreme Court could require a state litigant to seek relief in state court first. The Court could stress the important role state courts have in deciding equal protection cases. Courts review equal protection claims under either rational basis, intermediate scrutiny, or strict scrutiny. ${ }^{109}$ Each of these standards of review requires the state to identify its interest in passing a law. ${ }^{110}$ Perhaps state courts should get the first crack at reviewing equal protection challenges. After all, state courts may be better equipped to understand the interest proffered by their states. ${ }^{111}$

If claimants were forced to litigate equal protection cases in state court before going to federal court, commentators would panic. ${ }^{112}$ This

107. E.g., Andrew P. Napolitano, A Legal History of National Security \& Individual Rights in the United States: The Unconstitutional Expansion of Executive Power, 8 N.Y.U. J. L. \& LIBERTY 396, 553-54 (2014) ("Americans must be vigilant to protect our freedoms"); See also Kevin Williamson, Galileo Redux, NATIONAL REVIEW, (Apr. 3, 2016), http://www.nationalreview.com/ article/433582/free-speech-climate-science-first-amendment ("The First Amendment was expressly designed to protect political speech, the right to criticize one's government and its actions.").

108. Cf. Williamson Cty. Reg'l Plan. Comm'n v. Hamilton Bank of Johnson City, 473 U.S. at 194 (explaining that constitution is not violated until just compensation has been sought and denied). To be sure, some courts have tried to apply Williamson County when there have been allegations of discrimination. Islamic Cmty. Ctr. for Mid Westchester v. City of Yonkers Land Pres. Bd., No. 16-CV-7364 VB, 2017 WL 2804997, at 9 (S.D.N.Y. June 28, 2017). But see Temple B’Nai Zion, Inc. v. City of Sunny Isle Beach, 727 F.3d 1349, 1357 (11th Cir. 2013) (declining to apply Williamson County when plaintiff alleges land use decision was born out of discriminatory animus).

109. Fisher v. Univ. of Texas, 133 S. Ct. 2411, 2419 (2013) (Ginsburg, J. dissenting) (discussing strict scrutiny); United States v. Virginia, 518 U.S. 515, 567-68 (1996) (Scalia, J., dissenting) (discussing intermediate scrutiny); Williamson v. Lee Optical of Oklahoma Inc., 348 U.S. 483, 491 (1955) (rational basis).

110. Johnson v. California, 543 U.S. 499, 505 (2005) (discussing how all racial classifications must undergo strict scrutiny); Fisher, 133 S. Ct. at 2419 (discussing strict scrutiny); Turner Broad. Sys., Inc. v. F.C.C., 512 U.S. 622, 662 (1994); Lee Optical, 348 U.S. 483, 491 (1955) (rational basis).

111. See, e.g., Brief. for Respondent at 51-58, Obergefell v. Hodges, 135 S. Ct. 2584 (2015) (discussing Ohio's state interest in banning gay marriage against an equal protection challenge).

112. Cf. Jesus A. Osete, Voter suppression rears its ugly head, NoGAlES INT'L, (Mar. 29 , 2016), http://www.nogalesinternational.com/opinion/guest_opinion/voter-suppression-rears-itsugly-head/article_a62ce3e0-f52c-11e5-80ad-7751b9f506e4.html (describing problems with invalidating the preclearance measures of the Voting Rights Act, and emphasizing the importance 
terror would likely have nothing to do with issue or claim preclusion. Rather, civil rights advocates would probably decry a state-litigation rule for equal protection cases because it would appear that federal courts were trying to undermine the substantive protections of the Equal Protection Clause. ${ }^{113}$

It is hypocritical to condemn limiting access for First or Equal Protection Clause claims while arguing that Williamson County's ripeness rule should remain. Under current doctrine, someone who wants to bring a freedom of speech or equal protection claim does not have to go through state litigation. ${ }^{114}$ Yet the Court has not provided property owners this same dignity of federal review, even though the Fourteenth Amendment also protects one's right to just compensation. ${ }^{115}$

The state-litigation requirement unfairly relegates the Just Compensation Clause to second-class status. ${ }^{116}$ Because the Just Compensation Clause is like any other constitutional protection, it should be treated that way absent a compelling argument to the contrary. ${ }^{117}$ The Court has not made the affirmative case for the statelitigation requirement. ${ }^{118}$

of voting rights), with Ian Millhiser, When John Roberts Said Enough Racism in America to Justify the Voting Rights Act, THINKProgress, (Jun. 18, 2015), http://thinkprogress.org/justice/ 2015/06/18/3671107/two-years-ago-supreme-court-said-isnt-enough-racism-justify-voting-rightsact/ (describing problems with invalidating some measures of the Voting Rights Act).

113. Cf. Jeffrey Toobin, Justice Scalia's Shameful Joke, New YorKER, (Apr. 28, 2015), http://www.newyorker.com/news/daily-comment/on-gay-marriage-its-not-scalias-court (criticizing Justice Scalia's tone during argument for Obergefell v. Hodges); Michael Keegan, Cleaning up the Supreme Court's Democracy Mess, Huffington Post, (Aug. 25, 2014), http://www.huffingtonpost.com/michael-b-keegan/cleaning-up-the-supreme-c_b_5529257.html (criticizing the Court's invalidation of a provision of the Voting Rights Act).

114. To be sure, some courts have applied Williamson County to any case in which land use is involved. These cases simply highlight the absurdity of the Williamson County ripeness rule. It is not apparent to the author what state court litigation does to ripen an Americans with Disabilities Act case. See generally Eclipse Enters., Inc. v. Gulotta, 134 F.3d 63 (no issue when the First Amendment claim was first brought in federal district court).

115. See Chicago, Burlington \& Quality R.R. Co. v. City of Chi., 166 U.S. 226 (1897) (the Court found that nominal payment for a public right of way over a railroad was not a denial of the equal protection rights of the railroad company).

116. See Dolan v. City of Tigard, 512 U.S. 374, 392 (1994) (comparing takings clause with other constitutional provisions).

117. See id. ("We see no reason why the Takings Clause of the Fifth Amendment, as much a part of the Bill of Rights as the First Amendment or Fourth Amendment, should be relegated to the status of a poor relation in these comparable circumstances.").

118. See San Remo Hotel, L.P. v. City and Cty. of S.F., 545 U.S. 323, 351(2005) (Rehnquist, C.J., concurring) ("the Court has not explained why we should hand authority over federal takings claims to state courts ... while allowing plaintiffs to proceed directly to federal court in cases involving, for example, challenges to municipal land-use regulations based on the First 


\section{Williamson County Creates a Two-Tracked Justice system for the Have and Have-Nots}

Aside from treating constitutional protections differently, Williamson County creates a two-tracked justice system between the wealthy and the rest of society. Many homeowners, like Leslie and Ben, do not have the resources to deal with local governments' litigation gamesmanship. Litigation is expensive and most people have finite resources. ${ }^{119}$ At some point, rational people will simply give up because it will no longer be worth defending their rights, thus putting a de facto expiration date on the Takings Clause. ${ }^{120}$

The ripeness-removal trap contributes to a two-track justice system for the poor and the wealthy. First, property owners will generally be at a disadvantage litigating against the government because the government usually has more resources. ${ }^{121}$ Second, because property owners are suing the government under the Fifth Amendment, the government can remove their case to federal court. ${ }^{122}$ Moreover, once a property owner is in federal court, most circuits allow the government to send the plaintiff back to state court because of Williamson County. ${ }^{123}$ While the government may be able to financially afford this litigation, many property owners are unable to do so. ${ }^{124}$

Not all Fifth Amendment litigants will be at a disadvantage. The wealthy can afford to vindicate their rights while the average person will struggle to pay their legal bills. ${ }^{125}$ The wealthy will have an easier

Amendment").

119. Art Wittich, Are Private Property Rights an Endangered Species in Montana?, 21 MONT. LAW. 3, 3 (Apr. 1996).

120. But see Palazzolo v. Rhode Island, 553 U.S. 606, 627 (2001) ("Were we to accept the State's rule, the [post enactment] transfer of title would absolve the State of its obligation to defend any action restricting land use, no matter how extreme or unreasonable. A State would be allowed, in effect, to put an expiration date on the Takings Clause.").

121. See Eduardo M. Peñalver \& Lior Jacob Strahilevitz, Judicial Taking or Due Process?, 97 CORNELL L. REV. 305, 328-31 (2012) (discussing tool of judicial takings that government may use).

122. 28 U.S.C. $\$ 1441$ (2012).

123. See, e.g., Gelnett, 2015 WL 7454757.

124. Cf. Palazzolo, 553 U.S. at 627 (2001) (explaining that the takings clause should not have an expiration date).

125. Compare Gillian B. White, Inequality Between America's Rich and Poor Is at a 30-Year High, THE ATLANTIC (Dec. 18, 2014), https://www.theatlantic.com/business/archive/ 2014/12/inequality-21 (explaining that wealth inequality is increasing); with Gideon v. Wainwright, 372 U.S. 335, 344-45 (1963) (discussing how without legal aid for the poor, many indigent individuals may be " "put on a trial without a proper charger, and convicted upon incompetent evidence, or evidence irrelevant to the issue or otherwise inadmissible' in the 
time complying with the state-litigation requirement and a better chance at ultimately entering federal court. Indeed, the wealthy may not even have to face eminent domain proceedings in the first place. ${ }^{126}$ For instance, if a city is aware of a person's assets and the possibility of a prolonged legal battle, they might be reluctant to take any actions that may cause a taking. Instead, the government might prefer to target politically and economically vulnerable property owners because minorities and the poor make easier targets. ${ }^{127}$

\section{TOWARDS A SENSIBLE RESOLUTION OF WILLIAMSON COUNTY'S TRAPS}

To provide a solution for Williamson County's traps, this section proceeds in three parts. In the first section, I provide a roadmap for litigators to generate a case that would allow the Court to narrow Williamson County. In the second section, I explain how this minimalist solution undoes the Williamson County-San Remo and ripeness-removal traps-the two main problems discussed in this article. Finally, the third section briefly explains how the Court may respond if lower courts resist a narrowed Williamson County decision.

\section{A. The Minimalist Solution to the Williamson County Dilemma}

The major challenge in undoing Williamson County's problems has been getting the Court to reexamine the case. ${ }^{128}$ Since San Remo was decided, creating the Williamson County-San Remo trap, the Supreme Court has had many chances to revisit Williamson County, but has declined to do so. ${ }^{129}$ Arrigoni is the most recent denial and the

criminal procedure context" (citation omitted)).

126. Ilya SOMIN, THE GRASPING HAND: KELO V. CITY OF NEW LONDON AND THE LIMITS OF EMINENT DOMAIN 83 (The University of Chicago Press ed., 2015).

127. See Ryan Merriman, Closing Pandora's Box: Proposing a Statutory Solution to the Supreme Court's Failure to Adequately Protect Private Property, 2012 B.Y.U. L. REV. 1331, 134546 (2012) ("Liberals, on the other hand, object to the disproportionate impact economicdevelopment takings have on minorities and the poor."); Paul Boudreaux, Eminent Domain, Property Rights, and the Solution of Representation Reinforcement, 83 DENV. U. L. REV. 1, 47 (2005) (explaining that cities are more likely to condemn the homes of poor and minority communities if they "are concerned with improving their tax bases, [because] it simply is not economical to pay attention to the needs or desires of the poor.").

128. Circuit courts could minimize Williamson County's effects on property owners, but generally have not done so. But see Sansotta, 724 F.3d 533 (applying waiver rule); Guggenheim, 638 F.3d at 1116-18 (applying Williamson County in a narrow manner).

129. See, e.g., Arrigoni, 136 S. Ct. 1409; Kurtz v. Verizon N.Y., Inc., 135 S. Ct. 1156 (2015) (denial of certiorari); see also J. David Breemer, Ripeness Madness: The Expansion of Williamson County's Baseless "State Procedures" Takings Ripeness Requirement to Non-Takings Claims, 41 URB. L. 615, 616 n.11 (2009) (listing cases denying certiorari, asking Court to revisit Williamson 
closest the Supreme Court has come to addressing Williamson County, ${ }^{130}$ but only two Justices expressed interest in revisiting the case. Thus, for those who are concerned about Williamson County's effects, it is necessary to find the best way to get two more votes in support of certiorari. ${ }^{131}$

Many commentators have called for the Court to overrule Williamson County, ${ }^{132}$ and after San Remo, those calls have increased. ${ }^{133}$ Because of Justice Thomas's dissent in Arrigoni, property right advocates may feel emboldened to push the Court to overrule Williamson County. ${ }^{134}$ They should seek to have the case overruled. It is worth considering other ways to undo Williamson County's damage without asking the Court to take the extraordinary step of overruling the case. ${ }^{135}$

\section{B. The Court and Minimalism}

A problem for takings litigants seeking to overrule Williamson County is that the Court is a minimalist institution. This has been especially true since Chief Justice Roberts took the bench. ${ }^{136}$ "Minimalists try to decide cases rather than to set down broad rules; they ask that decisions be narrow rather than wide." 137 This theory requires jurists to decide no more than they must to ensure the resolution of a case. ${ }^{138}$ One common trait of a minimalist court is that

County).

130. Arrigoni, 136 S. Ct. at 1409.

131. Rogers v. Mo. Pac. R.R. Co., 352 U.S. 500 (1957), rev'd sub nom. Herdman v. Penn. R.R. Co., 352 U.S. 518, 519-20 (1957) (Frankfurter, J., dissenting) (discussing the "rule of four" to grant certiorari).

132. See Bernick, supra note 18, at 66 (citing law review articles calling for the Court to readdress Williamson County).

133. Keller, supra note 70, at 241 ("After the State Litigation prong is seen as judicial jurisdiction stripping masquerading as ripeness, this Note argues that the U.S. Supreme Court should eliminate the Williamson County State Litigation prong.").

134. See, e.g., Gideon Kanner, Great Dissent!, GIDEON's TrUMPET (Apr. 25, 2016), http:/gideonstrumpet.info/2016/04/great-dissent/ (endorsing the dissent); Robert H. Thomas, Quagmire Unabated: SCOTUS will Not Revisit Williamson County (Yet), INVERSE CONDEMNATION (Apr. 25, 2016), http://www.inversecondemnation.com/inversecondemnation/ 2016/04/scotus-will-not-revisit-williamson-county-yet.html (endorsing the dissent).

135. See Harris v. Quinn, 134 S. Ct. 2618, 2652 (2014) (Kagan, J., dissenting) (explaining that "special justifications needed to reverse an opinion must go beyond demonstrations (much less assertions) that it was wrong; that is the very point of stare decisis" in the context of potentially overruling case requiring compulsory union dues for collective bargaining).

136. Sykes, supra note 20, at 31 (discussing Chief Justice Roberts's preference to use minimalist techniques to avoid conflicts with the political branches).

137. Cass Sunstein, Foreword: Leaving Things Undecided, 110 HARV. L. REV. 4, 15 (1996).

138. Id. at 6 . 
it will decline to overrule previous cases, abiding by stare decisis to promote stability and predictability of the law. ${ }^{139}$

One theory suggests that denying certiorari is a form of minimalism. ${ }^{140}$ Professor Cass Sunstein is the most notable proponent of this theory. ${ }^{141} \mathrm{He}$ argues that the Court may deny certiorari when it wants more information about the legal facts of a case, when it is prudent to wait before addressing a major issue, or when it is trying to avoid issuing an incorrect decision. ${ }^{142}$ As Professor Sunstein observes, "Denials are reasonless. They are entirely rule-free and untheorized." ${ }^{143}$ Because denial of certiorari is the easiest way to leave a case undecided, it is appropriately characterized as a form of minimalism.

Knowing the Supreme Court is a minimalist institution, and assuming denying certiorari is a form of minimalism, takings litigants probably should not ask the Court to overrule Williamson County. ${ }^{144}$ If a litigant does so, the Court may follow its minimalist tradition and simply deny review. For this reason, many recent property rights cases before the Court have merely asked the Court to refine its prior decisions. ${ }^{145}$ For example, San Remo was the last case in which the Court discussed Williamson County in significant detail. ${ }^{146}$ There, the petition only asked whether issue preclusion applied under that precise factual scenario. ${ }^{147}$

Given that the Court likes to act in a minimalist fashion, the next step for those seeking to undo Williamson County's damage is to findor design - a case that would limit Williamson County and San Remo's reach, but does not ask the Court to overrule either case. The ideal case would feature a petitioner that had plausibly complied with the ripeness requirements, but did not litigate in state court. If a petitioner had tried to comply with Williamson County, the Court may be more

139. Sykes, supra note 20, at 19.

140. Sunstein, supra note 137 , at 15 .

141. Id.

142. Id. at 51.

143. Id. at 22 .

144. Certainly, one can list many cases over the last decade in which the Supreme Court explicitly overruled its prior cases, but none of these involve property rights.

145. See, e.g., Kelo, 545 U.S. 469 (distinguishing case from other public use suits); San Remo, 545 U.S. 323 (not asking the Court to overrule Williamson County).

146. Although the Court did discuss Williamson County in Stop the Beach, 130 S. Ct. at 2609, it only discussed the prudential nature of the decision; it did not address Williamson County's tension with other doctrines.

147. Petition for Writ of Certiorari, San Remo Hotel, at ii (Question Presented), available at https://www.smallprop.org/downloads/SanRemoPetition.pdf. 
likely to grant certiorari because it allows them to simply reject an overly broad reading of the adequate state procedure requirement. ${ }^{148}$ Litigants like Leslie and Ben-a middle-class couple who tried to comply with the abstruse legal requirements-may appear especially sympathetic. ${ }^{149}$

\section{Using Williamson County's Language to Design a Minimalist Case}

To find the best "cert-worthy" case, it is useful to start with Williamson County's plain language. According to Justice Blackmun, aggrieved property owners must "seek compensation through the procedures the state has provided for doing so." "150 "II]f a State provides an adequate procedure for seeking just compensation, the property owner cannot claim a violation of the Just Compensation Clause until [he] has used the procedure and been denied just compensation." "151 What constitutes "an adequate procedure" is not defined in Williams County, but a few observations are noteworthy. Justice Blackmun never says that "adequate procedure" requires state court litigation, like so many circuit courts have claimed. ${ }^{152}$ Moreover, "an" and "procedure" are singular terms, suggesting that property owners need only pursue one procedure.

An attractive minimalist case would involve a takings litigant who used a non-judicial, state-sanctioned procedure provided for obtaining compensation instead of seeking compensation through state court. After being denied compensation through this procedure, the litigant

148. Indeed, the Court has recently taken the opportunity to narrow extremely broad readings of other statues. McDonnell v. United States, 136 S. Ct. 2355, 2371-72 (2016) (rejecting broad interpretation of the Hobbs Act); Yates v. United States, 135 S. Ct. 1074, 1088-89 (2015) (rejecting broad interpretation of Sarbanes-Oxley Act); Bond v. United States, 134 S. Ct. 2077, 2090 (2014)

(rejecting broad interpretation of the Convention of the Prohibition of Development and Use of Chemical Weapons). Although these cases have other elements that are not an issue in takings cases, such as the rule of lenity and criminal law issues, it is still useful to see how the Court resolve tricky issues. Statutory interpretation cases are especially useful for this article because I suggest the Court engage in a pseudo-statutory interpretation of its prior opinion.

149. See Margaret Meriwether Cordray \& Richard Cordray, The Philosophy of Certiorari: Jurisprudential Consideration in Supreme Court Case Selection, 82 WASH. U. L. Q. 389, 395 (2004) ("At a more concrete level, the choice of a particular case, with its peculiar set of facts, among the many that are generally available to resolve an issue can influence the scope and content of the Court's opinion on the merits - and possibly the outcome.").

150. Williamson Cty., 473 U.S. at 194.

151. Id. at 195 (emphasis added).

152. See, e.g., Save More Food Mkts, Inc. v. Wis. Dep't of Transp., No. 16-cv-447-jdp, 2016 WL 4131866 (W.D. Wisc. Aug 3, 2016). 
seeks compensation in federal court. Then, after a circuit court holds that the takings litigant's claim is not yet ripe, because he has not sought compensation in a state court, he petitions for certiorari with a question presented similar to this, "Whether a non-judicial state procedure, in which a property owner applies to a state agency to obtain just compensation for a taking, is an adequate procedure for obtaining compensation that satisfies Williamson County's ripeness requirements." 153

This question presented does not ask the Supreme Court to overrule its prior case, and it allows the Court to make a narrow ruling. All the Court must answer is whether the petitioner complied with Williamson County's requirements. ${ }^{154}$ If it holds that the non-judicial procedure satisfies Williamson County's requirements, it would eliminate the state-court litigation requirement. ${ }^{155}$ This ruling would confirm what commentators and jurists have been saying for decades: State courts do not need to review a takings claim before a Takings Clause violation is ripe. ${ }^{156}$ Additionally, the Court would not be breaking new ground; some courts have held that "an 'adequate process' for state compensation can also be administrative relief such as a state claims commission which awards monetary damages." ${ }^{157}$

One lingering difficulty is that "adequate procedure for seeking compensation" is still vague. To cure Williamson County's defects, "an adequate procedure" will have two components: (1) it must be nonjudicial, and (2) it should be a procedure that allows the municipality to provide compensation. A good rule of thumb for the first prong would be to ask whether the procedure was created by the legislature, such as an agency, commission, or board. ${ }^{158}$ If the procedure was

153. Whether the Court would grant certiorari is certainly a different question. The Court will typically look to resolve circuit splits or questions of national importance. Sup. Ct. R. 10. Arrigoni suggests that two justices see resolving Williamson County's litigation trap as an important question. But to make this case "cert-worthy," it may take more strategic litigation throughout the country to create a circuit split.

154. See 28 U.S.C. $§ 1738$ (2012) (applying full faith and credit statute in full judicial proceedings).

155. San Remo, 545 U.S. at 348 (Rehnquist, C.J., concurring) ("It is not clear to me that Williamson County was correct in demanding that, once a government entity has reached a final decision with respect to a claimant's property, the claimant must seek compensation in state court before bringing a federal takings claim in federal court."); Overstreet, supra note 98, at 118-20.

156. Overstreet, supra note 98, at 118-20.

157. Id. at 118 (citing MAK Co. v. Smith, 763 F. Supp. 1003, 1005 (W.D. Ark. 1991)).

158. See BLACK'S LAW DICTIONARY 17 (4 ${ }^{\text {th }}$ pocket ed. 2011) (defining "administrative proceeding" as "A hearing, inquiry, investigation, or trial before an administrative agency, usu. adjuratory in nature but sometimes quasi-legislative.”). 
created by the legislature, that non-judicial procedure would likely satisfy the first prong. ${ }^{159}$ The procedure must be non-judicial to avoid issue preclusion. ${ }^{160}$ As to the second prong, courts should understand compensation to be a payment to recoup for a loss. ${ }^{161}$ Thus, a takings litigant would satisfy Williamson County's requirement when he seeks a monetary payment for a taking from an agency, commission, or board.

Several examples of what should be adequate state procedures might help illustrate what would ripen a case for federal review. ${ }^{162}$ For instance, the California Tort Claims Act would probably be an adequate procedure. ${ }^{163}$ The law provides governmental entities and takings plaintiffs a chance to negotiate a settlement for an alleged taking. ${ }^{164}$

For example, say Sacramento, California declares that a plot of land is an environmentally sensitive zone, thus preventing its property owner from building anything on their plot. ${ }^{165}$ Because Sacramento has denied all economically viable use of their land, the property owner wants to file a per se takings claim. ${ }^{166}$ Knowing Williamson County's requirements, the property owner first seeks compensation from a board that Sacramento established to negotiate settlements for inverse condemnation claims. If Sacramento's board pays compensation, everyone is better off. The owner is paid, Sacramento does not have to litigate, and the federal dockets remain clear. If the city declines to

159. Cf. id. at 416 (defining "judicial" as "Of, relating to, or by the court or a judge.").

160. See San Remo, 545 U.S. at 347 ("Whatever the merits of that concern may be, we are not free to disregard the full faith and credit statute solely to preserve the availability of a federal forum.").

161. See generally Tim Kowal, The Restitutionary Approach to Just Compensation, 9 Chap. L. Rev. 463, 466-74 (2006) (arguing for a broader conception of the Just Compensation Clause to include restitution payments).

162. One notable circuit case is Temple B'Nai Zion, Inc. v. City of Sunny Isles Beach, 727 F.3d 1349, 1359 (11th Cir. 2013). There, the Eleventh Circuit explained that "the record is sufficiently developed - thanks in part to two lengthy quasi-judicial hearings held before the Preservation Board and the City Commission - that the issues we today deem ripe are clearly primed and at the ready for judicial resolution." Id. (emphasis added). My suggestion is to hold that non-judicial remedies are sufficient; but quasi-judicial remedies would also remove the ripeness-removal and the Williamson County-San Remo traps because there still would be no final agency decision.

163. Cal. Gov’t Code $\S \S 935-935.2$ (2012).

164. Id.

165. See PLF clients win in settlement with Tahoe agency, Pac. Legal Found. (Dec. 10, 2015), https://pacificlegal.org/plf-clients-win-in-settlement-with-tahoe-agency/ (informing that TRPA was sued for "taking” a couple's property).

166. See Lucas, 505 U.S. at 1019 (declaring when a property owner is denied all economically viable use of their property, it is a per se taking). 
pay compensation, then the property owner's claim would be ripe under Williamson County because he has sought compensation through an adequate state procedure.

The administrative appeal provided in Mecouch v. Pension Board of the Employee's Retirement System is also illustrative of a procedure for seeking compensation that should satisfy Williamson County's requirements. ${ }^{167}$ In that case, George Mecouch purchased "service credits" from the Pension Board of the County of Milwaukee to ensure that his retirement benefits would vest. ${ }^{168}$ After receiving confirmation that his retirement benefits would vest, Mecouch retired. Twenty-five years later (and four years after he had started drawing a pension), the pension board informed him that it had improperly allowed him to purchase service credits. ${ }^{169}$ Thus, the pension board suspended his pension. ${ }^{170}$ Mecouch sought to have the pension board reinstate his payments. ${ }^{171}$ First, Mecouch sought to have his payments reinstated through the pension board's appeal process. ${ }^{172}$ The appeal board did not restore his payments, ${ }^{173}$ although it did say that Mecouch's claim was ready for judicial review. ${ }^{174}$

Because the board informed the litigant that, "he was entitled to seek judicial review," his claim should be ripe for review in state or federal court. ${ }^{175}$ The procedure was enough to secure compensation because if the board had agreed with Mecouch, his money would have been returned and his takings argument rendered moot. Because Mecouch used a procedure that could have provided him all the relief he was seeking, his claim should have been ripe under this proposed test. ${ }^{176}$

On the other hand, commentators who have called for Williamson County to be overruled may not be satisfied with narrowing it. Property rights advocates may argue that this procedure is unnecessary, noting - and correctly so-that a landowner suffers a

167. Mecouch, 184 F. Supp. 3d at 684.

168. Id. at 686 .

169. Id.

170. $I d$.

171. Id.

172. Id.

173. $I d$.

174. $I d$.

175. Id.

176. Id. at 690 . To be sure, the Western District of Wisconsin held that Mecouch's claim was not ripe because his case had not been ripened through state court procedures because Wisconsin's constitution provides a takings claim. Id. 
taking as soon as any government official denies just compensation. ${ }^{177}$ These advocates may argue that any minimalist case should acknowledge when a constitutional injury occurs.

This minimalist decision would recognize the scope of a constitutional injury and recognize that federal courts need flexibility. Courts see many meritless takings claims. Pro se litigants - and some low-quality attorneys-often sue cities for takings under strained theories. ${ }^{178}$ Many pro se litigants poorly design their cases, causing their suits to burden an already overworked judiciary. ${ }^{179}$ By keeping a requirement for takings plaintiffs to use a non-judicial state procedure, lower courts provide these plaintiffs a reliable way to get compensation while relieving pressure on federal judges. In addition, if a plaintiff fails to get compensation, through a state non-judicial procedure, they can then go to federal court.

The minimalist solution also would not undo Williamson County's prudential nature. If a landowner suffers an egregious taking and files a well-crafted complaint, and the facts are well developed, a federal court may choose to hear the case immediately without requiring him to seek compensation through a non-judicial procedure. ${ }^{180}$ By narrowing "an adequate procedure for receiving compensation" to a single state non-judicial procedure, the Court would provide federal courts maximum flexibility while protecting property rights.

177. J. David Breemer, You Can Check Out But You Can Never Leave: The Story of the San Remo Hotel - The Supreme Court Relegates Federal Takings Claims to State Courts Under a Rule Intended to Ripen the Claims for Federal Review, 33 B.C. Envtl. Aff. L. Rev. 247, 291 (2006) (citing Berger \& Kanner, supra note 15, at 694) ("The fundamental principle underlying this conclusion - that an action for a taking exists only if the challenged invasion of private property occurs 'without just compensation' - is not controversial, but the conclusion that compensation can be deemed lacking only after state court litigation is dubious.").

178. See, e.g., Jackson v. Vill. of Western Springs, No. 14 C 3414, 2014 WL 5543844 (N.D. Ill. Nov. 3, 2014); Jarvis-Orr v. Twp. Of Hartford, No. 1:11-CV-1066, 2012 WL 6737740 (W.D. Mich. Nov. 30, 2012); Moes v. Woodward, Nos. 1:11-CV-912, 1:12-CV-1092, 2012 WL 5830596 (W.D. Mich. Nov. 16, 2012).

179. See, e.g., Jackson, 2014 WL 5543844, at *1 ("The 100-page, 447-paragraph Complaint is hard to follow, but it appears that all of Jackson's claims are related to these zoning decisions and the Defendants' activities surrounding the decisions."); Jennifer Bendery, Federal Judges are Burned Out, Overworked And Wondering Where Congress Is, HUFFINGTON POST, (Sep. 30, 2015), http://www.huffingtonpost.com/entry/judge-federal-courts-vacancies_us_55d77721 e4b0a40aa3aaf14b (last visited Oct. 29, 2017) (describing how one federal judge works up to 75 hours a week and at least one full day every weekend to keep up with workload).

180. Along with Mecouch, consider Bendorf v. Ojai Basin Groundwater Mgmt. Agency, No. CV 11-3877-DSF SP, 2012 WL 3867352 (C.D. Cal. July 16, 2012). The plaintiffs filed a pro se complaint after trying to work through the issues with local agencies. That said, the court in Bendorf dismissed the case because the pro se plaintiff had not complied with Williamson County. 
Though Williamson County has caused much heartache for property owners and their advocates, the Supreme Court does not seem eager to revisit the case. ${ }^{181}$ Thus, it is necessary to present a case that would attract the Court's attention. An ideal case may be one in which a takings litigant used a non-judicial state procedure, such as the California Tort Claims Act, to obtain compensation, but was still denied access to the federal courts because he did not seek compensation in state court. Such a case would highlight how a good actor who tried to comply with the Court's strict requirements could not get relief, even after complying. To limit Williamson County's damage, takings plaintiffs should leave an opening for the Court to reject the state-court litigation requirement without overruling Williamson County.

\section{Rejecting the State Litigation Rule Would Eliminate the} Ripeness-Removal and Williamson County-San Remo Traps

The immediate benefit from this ruling is that it would eliminate the Williamson County-San Remo and ripeness-removal traps. If a state procedure, such as the California Tort Claim Act, ripens a landowner's case, then issue preclusion will never arise because using these procedures does not result in a final judgment. Additionally, federal courts could continue to decline to hear poorly developed or nonsensical takings claims. ${ }^{182}$ Landowners will also no longer fall prey to unfair gamesmanship tactics. In other words, eliminating the Williamson County-San Remo trap through my minimalist proposal ensures that property owners do not resort to federal courts as a first stop, but it still guarantees that property owners will be able to access the federal judiciary, while preserving judicial discretion to prevent docket overrun. ${ }^{183}$

In addition, holding that a state non-judicial procedure could satisfy Williamson County would also eliminate the ripeness-removal

181. See Arrigoni, 136 S. Ct. at 1412 (dissenting from denial of certiorari, even though the case appeared to be an appropriate vehicle to resolve the Justices' individual concerns about Williamson County).

182. See, e.g., Jackson v. Vill. of Western Springs, No. 14 C 3414, 2014 WL 5543844 (N.D. Ill. Nov. 3, 2014); Jarvis-Orr v. Twp. Of Hartford, No. 1:11-CV-1066, 2012 WL 6737740 (W.D. Mich. Nov. 30, 2012); Moes v. Woodward, Nos. 1:11-CV-912, 1:12-CV-1092, 2012 WL 5830596 (W.D. Mich. Nov. 16, 2012).

183. To be sure, district courts often deal with meritless cases about a wide range of issues. See, e.g., Seed.S of Ibrahim Corp. v. Comm. of Pa., CIV.A. No. 88-4329, 1988 WL 131380 (E.D. Pa. Dec. 7, 1988). It is simply unclear why courts single out takings claim. If a frivolous claim is filed, courts should simply dismiss the case rather than apply an odd work around. 
trap. This would prevent governments from using Williamson County as a stalling tactic. If a takings litigant seeks compensation through a non-judicial state procedure, then the government cannot seek removal because the case is not in court. ${ }^{184}$ After a takings litigant uses a non-judicial procedure for seeking compensation, the litigant's claim would be ripe, and he could sue immediately in federal court. ${ }^{185}$ Alternatively, if a takings plaintiff sues in state court and has his case removed to federal court, he would not be sent back to state court for failing to satisfy Williamson County because he satisfied Williamson County by seeking compensation through a state non-judicial procedure. ${ }^{186}$

Thus, a narrow holding that a state non-judicial procedure can satisfy Williamson County would undo the Williamson County-San Remo trap. After compensation is denied in a state non-judicial procedure, a takings claim would be ripe for judicial review. ${ }^{187} \mathrm{~A}$ municipality also could not argue that issue preclusion applies because there is no final state court judgment, as was the case in San Remo. ${ }^{188}$ Thus, allowing the litigant to keep his suit in federal court would not violate the Full Faith and Credit Clause.

To be sure, Williamson County would retain the prudential exception for when a municipality engages in gamesmanship or a case is well-developed, ${ }^{189}$ and the futility exception would still apply. ${ }^{190}$ By using minimalism and holding that a state non-judicial procedure satisfies Williamson County, the Supreme Court could undo the Williamson County-San Remo and ripeness-removal traps.

184. See 28 U.S.C. $§ 1441$ (a) (2012) (removal only applies to case filed in state court).

185. See Williamson Cty., 473 U.S. at 195 (discussing adequate procedures for providing compensation).

186. See supra Section IV.A.

187. $I d$.

188. San Remo, 545 U.S. at 336 ("The modern version of the statute, 28 U.S.C. $\S 1738$, provides that judicial proceedings shall have the same full faith and credit in every court within the United States and its Territories and Possessions as they have by law or usage in the courts of such State.") (quotations and citations omitted).

189. See Hacienda Valley Mobile Estates, 353 F.3d at 655 ("The plaintiff must have obtained a final decision from the governmental authority charged with implementing the regulations and must have pursued compensation through state remedies unless doing so would be futile.").

190. See Adam Bros. Farming, Inc. v. Cty. of Santa Barbara, 604 F.3d 1142, 1148 (9th Cir. 2010) ("As this case raises only prudential concerns, we have the discretion to waive the requirements of Williamson County, assume that ripeness is met and continue with our analysis."). 


\section{E. What if Lower Courts or Municipal Governments Continue to Abuse Williamson County?}

Even if the Supreme Court holds that a non-judicial state procedure can be an "adequate state procedure" - thus rejecting state court litigation as a necessary ripening procedure-lower courts may resist. They may hold that objectively reasonable state non-judicial procedures for obtaining compensation do not satisfy Williamson County's requirements. ${ }^{191}$ This would continue to distort Williamson County. Some judges surely would resist changing Williamson County because its requirements bar a category of cases from federal court, thus lowering the courts' case loads. ${ }^{192}$

Though the minimalist ruling I propose may lead to courts distorting Williamson County, the Supreme Court's watchful eye would dissuade lower courts and municipalities from playing games. In his recent dissent from denial in Arrigoni, Justice Thomas suggested that the Court knew that Williamson County has spawned "confusion in the lower courts"193 and "inspire[d] gamesmanship in the lower courts." 194 Chief Justice Rehnquist also argued in his San Remo concurrence that the state litigation requirement is nonsensical. Thus, it would be unwise for lower courts to further distort Williamson County if the Court corrected some of the problems that Justice Thomas and Chief Justice Rehnquist identified, yet left Williamson County breathing.

If lower courts continue to distort Williamson County, the Supreme Court could overrule it. This would be consistent with the Court's practice of narrowing, questioning, and weakening its precedents before overruling them. ${ }^{195}$ In recent years, the Court has first issued a narrow ruling before issuing broad decisions in cases

191. Indeed, some courts have done so in other similar land use cases. See, e.g., Cal. Bldg. Indus. Assoc. v. San Jose, 189 Cal. 4th 435 (2015) (rejecting theory of legislative exaction, despite strong precedents of Koontz v. St. John's River Water Mgmt. Dist., 133 S. Ct. 2586 (2013), Dolan, 512 U.S. 374, Nollan v. Cal. Coastal Comm'n, 485 U.S. 825 (1987) (supporting that theory); see also Cal. Bldg. Indus. Ass'n v. San Jose, 136 S. Ct. 928 (2016) (Thomas, J., concurring in denial of certiorari) ("For at least two decades, however, lower courts have divided over whether the Nollan/Dolan test applies in cases where the alleged taking arises from a legislatively imposed condition rather than an administrative one.").

192. Cf. Grace E. D'Alo, Reflections on Pennsylvania's ADR Community: Paradise, Pragmatism, \& Progress, 108 Penn St. L. Rev. 309, 310 (2003) (discussing general desire from courts to decrease their caseload, and using alternative dispute resolution methods to do so).

193. Arrigoni, 136 S. Ct. at 1411

194. Id. at 1409 .

195. Compare N.W. Austin Mun. Util. Dist. No. One v. Holder, 557 U.S. 193 (2009), with Shelby Cty. v. Holder, 133 S. Ct. 2612 (2013). 
involving campaign finance, voting rights, and gay marriage. The Court may do the same in a land use case if it is forced to revisit Williamson County after making a minimalist decision.

\section{CONCLUSION}

Over the past three decades, Williamson County has caused property owners much heartache. Takings litigants often try to comply with Williamson County's requirements, only to find themselves caught in either the ripeness-removal or Williamson County-San Remo traps. This result is unjust because it deprives property owners of a forum to vindicate their basic constitutional rights; property rights are not secondary. Williamson County may also cause local governments to target poorer individuals for takings. Fortunately for property owners, some members of the Supreme Court are ready to review Williamson County, though a few more votes are needed before certiorari is granted.

To encourage the Supreme Court, property rights advocates should craft an attractive case. Based on the Court's current composition, it is best to present the Court with the opportunity to make a minimalist ruling. In the Williamson County context, this means that property owners should present a case that asks the Supreme Court whether a non-judicial state procedure for seeking compensation, like the California Tort Claims Act, satisfies Williamson County's requirements. If the Court holds that it does, it would eliminate any notion that state court litigation is necessary to satisfy Williamson County. This would also undo the Williamson County-San Remo and ripeness-removal traps.

Even with a positive ruling, there is more to be done. Williamson County has two prongs. This article solely focused on the second prong: determining what an adequate state procedure is. Even after narrowing the adequate state procedure prong, the Court should still solve the issues of the finality prong, which is not discussed in this article. ${ }^{196}$

The Court would eliminate several hurdles for landowners by narrowing Williamson County. My solution would normalize how property rights are treated in the United States. Both liberal and conservative jurists recognize that property rights are a fundamental

196. See Overstreet, supra note 98, at 98-100 (discussing MacDonald, Sommer, \& Frates v. Cty. of Yolo, 473 U.S. 340 (1986) and the "meaningful application" and "reapplication" process in determining whether a county decision is final). 
aspect of the Constitution. ${ }^{197}$ Interpreting adequate procedure for obtaining compensation to include non-judicial state procedures would help put property rights on equal footing with other rights.

197. See, e.g., Arrigoni, 136 S. Ct. at 1411 (Justice Thomas criticizing the court for transforming property rights into a secondary right); Arkansas Game \& Fish Comm'n v. United States, 133 S. Ct. 511, 518 (2012) ("The Takings Clause is designed to bar Government from forcing some people alone to bear public burdens which, in all fairness and justice, should be borne by the public as a whole.") (citation and quotation omitted). 